\title{
Playing, Space and Gender
}

\author{
Sopa Siti Marwah ${ }^{1, *}$ \\ ${ }^{1}$ University of Garut, Garut, Indonesia \\ *Corresponding author. Email: shofaahmad2@gmail.com
}

\begin{abstract}
This paper aims to explore how children use the limited playing area in a densely populated area in Bandung. Based on three weeks focused ethnography study, this paper attempts to see how the children use the playing area and to what extent the playing becomes gendered. The information was collected through participatory observation by the first author. The information was then analyzed the information using grounded theory. Using a post-developmentalism approach, the findings of this study reveals that they segregate the playing area based on the children's gender. Some playing is dominated by the boys, and it excludes most of the time the girls from playing. It imposes the girls' greater control that prevents them to engage in some playing.
\end{abstract}

Keywords: Playing, gender and space

\section{INTRODUCTION}

Playing is a very important activity for the development of children, but the game must be on the initiative of the child and be done with a sense of fun,because if it is done with a sense of fun it will create a learning process for children (Mutiah, 2010). The process of development in playing is important to children as it is the development of language, cognition, and social competence (Myck-wayne, 2011; Wallerstedt \& Pramling, 2012; Bodrova \& Leong, 2013). Through a pleasant experience with the use of materials, objects, and support for adults, it will help the development of children optimally (Mutiah 2010; Kosanke \& Warner, 1990; Singer \& Singer, 2000). The existence of space is something that is very vital because the space becomes the scene of the events (Mutiah, 2010). Playroom (Children Playground) is a place designed for children to play freely (Baskara, 2011). However, the availability of open spaces in residential areas housing has been significantly reduced. Most homes already have a yard with KDB greater than $90 \%$, here the child's need of a place to play is often defeated by the interests and needs of adults. In addition, the UN noted predictions estimated that up to 2025 , half of the children in the world will live in cities. The children will gradually lose the playground (Saragih, 2003; Patilima, 2004).

The availability of playroom fulfills the conditions of influence on growth and development. Because playroom is a means for children to learn about negotiating, communicating, perspective, thoughts and feelings (Mutiah, 2010), in the children's playroom they also learn about the play and the games that follow the influence of gender and age in the game (Bowen, 2016). Children in playroom showed significant factors to establish gender behavior (Rönnlund, 2015; Clark \& Paechter, 2007; Blaise,
2014; Bartholomaeus 2016). Gender stereotypes often appear in the playroom (Wohlwend, 2012). Geographical research on gender looks at the boundaries between men and women, highlighting ways of power and environmental experience (Staeheli \& Kofman, 2013; Cope, 2004; Fincher, 2013; Nagar, 2004).

Research on playing illustrates what is considered a stereotype which is the difference between boys and girls (Chapman, 2017). Boys are shown to be more active in the girl's playroom (Mayeza, 2016, Harten, Olds, \& Dollman, 2008). One example in the boys' playroom is that it is always illustrated by often choosing risky games while girls do not choose to play risky games (Karniol, 2009; Mayeza, 2016; Jun, Chen \& Chen, 2010). How boys use more space outside and girls use more space inside (Adriany, 2013). Although there have been studies that discusses the effects of gender play, but studies that combine the playroom seen from a gender perspective is still limited. Thus the researcher wanted to know how in a densely populated slums what can girls do and if boy does the same.

\section{LITERATURE REVIEW}

\subsection{What is a Post-Developmentalism}

Post-developmentalism is a term used for a variety of theoretical perspectives that take a social constructionist understanding of difference and identity as a starting point to receive gender subjectivity (Blaise, 2014), Postdevelopment is not the dismantling of cynicism but rethinking the meaning of development built so far, where this can be an alternative of a universal perspective. (Abdullah, 2007), As an example Walkerdine (1993) stated that developmentalism criticized paradigm where the child 
just made the object, another critic against developmentalism assumes that the standard of child development always refers to the standard of children's development in the global north so that the lens of postdevelopmentalism it is seen as a colonialism process, where children outside the global are forcing the north as global north. Post-developmentalism try to give an alternative view, which is that the same children who grow up in the global north is not always the same children who grow up in Indonesia. Post-developmentalism creates a space for other perspectives that are useful to understand the aspects of subjectivity children (Blaise, 2014).

\subsection{How Postdevelopmentalism Is Used In Understanding The Concept Of Space And Play}

Post-developmentalism Indoor play is how Postdevelopmentalism tries to understand the concept of subjectivity of children's play. Like for example, the research conducted by (Saragih, 2001) shows that a child can be considered mature if they can play fair in a special playroom for children. Though children often play in places that are not reasonable such as rivers, roads and in places that are prohibited. Similar to the results of research (Gold, 2007) shows the results of the study found that many playgrounds in residential are unused, yet children just love playing time limited time such as after school and mealtimes. They played in an empty field, around the house, in front of the house or on the sidewalks. Just as research (Dewayani, 2011) adults always try to find anideal play room, what is ideal for an adult may differs from what is considered to be ideal for the children themselves. This post-developmentalism view tries to understand the concept of playing from the child's perspective.

\subsection{How Postdevelopmentalism Can Be Used in Understanding the Concept of Gender}

Post-developmental perspective on the concept of a child's play is to explain how each viewpoint differs using different angles in rationality and intersectionality to understand how gender is constructed (Blaise, 2014), by putting more emphasis on the gender aspects of a person's masculinity or femininity, both men and women so that they are nonpermanent, unnatural and highly influenced by culture (Adriany \& Warin, 2014). Thus gender is a good division of roles and responsibilities for men and women laid down by the cultural and social system (Fakih, 2008).

\section{PRE-RESEARCH METHODOLOGY}

\subsection{Design}

This research uses the qualitative method with a focus on ethnography. The reason why it is called the focus of ethnography is because it is a field trip short of the real ethnography, where it is still having an ethnography focused approach, keeping the essential nature of ethnography (Wall, 2014), What distinguishes it is a short field visit but requires intensive data analysis, using records, focus and communicative activities (Knoblauch, 2005), This research was conducted in a densely populated alley in the northern Bandung area. This study involved children from ages 4 to 6 years who played in the area.

\subsection{Participant}

The data collection is done by using participatory observation, this is done because it is difficult for an adult researcher to understand life from a child's perspective except to follow the activities of these children (Punch, 2016). That is why observation is the proper method to examine the child. In conducting observation for one month the researcher was in the field from 4 to $6 \mathrm{pm}$, the researcher then would come to mingle and interact with children in the playroom, sometimes the children would invite the researcher to be involved in their games. There are three locations play area which is the focus of the first study on the highway, Gedong 2 (name children's play area) and alley Sergeant Surip that is close to their proximity, then the researcher would record the activity that happens in the children's playground.

\subsection{Analysis}

Analysis of the data in this case uses data analysis grounded theory. Systematic design of the grounded theory emphasizes the use of data analysis steps such as coding (Charmaz, 1990, 2000, 2006). In coding, the results of observations and interviews, the researcher developed their own code to show several themes (Al-Wasilah, 2015, p. 147).

\subsection{Ethics Issues}

When the researcher was on the field the researcher needs to anticipate the ethical issues that arises in the research (Hesse-Biber \& Leavy, 2010; Punch, 2016) In the search for information the researcher have to remember about ethical limits to protect the participants (Cresswell, 2015, p. 458). Ethnographer does not just consider the informant but must 
take responsibility to protect, the rights, interests and sensitivities that of the informant (Spradley, 2007). Moreover, in this research that included adults and children, the researcher needs to maintain confidence in the face of the informant (Israel \& Hay, 2006). By using the research ethical issues. Patton-Imani (2002) offers ethical issues that can be used while in the field such as reciprocity, risk assessment, informed consent and confidentiality of access and ownership of data (Adriany, 2013).

\subsubsection{Gaining consent}

I can translate the agreement as the consent of the informant to take part in the study without coercion (Warin, 2011). Researcher create a written permission that they will ask adults to sign. The contents of the permission explained the importance and sensitivity of the informant. Such as personal data of informants, disguised name/ initials (Cresswell, 2016), and images that will not be spread publicly unless the researcher gets permission (AERA Council, 2011; British Educational Research Association, 2011)

When researcher study with children will ask for permission to parents and ask for approval of the child to take part in research, researcher will conduct that (AERA Council, 2011). We can identify approval in children through verbal exhibits characteristic willingness, if not willing to nonverbal children usually show as anxiety and fear when interviewed (Warin, 2011; Adriany, 2013).

\subsubsection{Privacy and confidential}

Privacy and Confidential means to maintain the privacy and identity of the informant (Adriany, 2013). Informants should know the detail that participation and interaction for the research includes the use of electronic equipment (AERA Council, 2011; British Educational Research Association, 2011). In protecting the privacy of informants the researcher will ask permission from the informant using electronic tools such as recording, taking pictures, and using other electronic devices. The researcher would explain informant how the researcher will take the picture, such as what kind of picture would be taken (taking a picture of the back of a child's body and not revealing the child's face).

\subsubsection{Power relations}

The first subject was a child, in which the researcher is more mature than the children so that the researcher's perspective is likely going to be different from the child's view, because the researcher is someone who can think differently from a child. The second informant was an adult. The relation of power can be seen between the positions of researcher as a postgraduate student of Early Childhood Education, whereas the research informants are adults who may be better educated, or their education can also be lower than the researcher but having a much higher experience than the researcher. The researcher worries that by using an observer perspective it will have a more dominant position than the informant, which can cause bias in the research.

For both of the problems mentioned above, the solution is the researcher to participate in community activities, such as helping and cooperation. Such activities are helping the local community in teaching children to learn in mosques, where the researcher can also use this for the purpose of getting closer to children.

\section{RESULTS \& DISCUSSION}

Presented below are the results of a comprehensive study of densely populated with a focus on two aspects including how boys and girls use play areas and how parents play a role in play areas.

\subsection{Playground Area}

When Zahra, Cinta and Zaki are playing jumping rope suddenly boys aged 4-5 years and adults comes towards them (children of junior high). Zahra, Cinta and Zaki then stood up, tidy up the rubber on the fence and then leaves the Gedong 2. The activity was then continued by the boy playing football, when the researcher asked Zahra on the reason why she left, Zahra replied that there was a boy so the game was stopped. (4, August 2017)

The results of the observation suggest that girls and boys does the jump rope activity together but the game had to be changed when there is a boy who wants to use the play area. Children who previously used the play area rushed away because there was a boy who wanted to use the play area.

"The researcher is sitting on the terrace to buy snacks from who seemed like Julaikha's mother, who is busy serving children who buys from her. The women beside Julaikha's mother have a son who occasionally approached her mother to ask for a drink and then continue to play, the boys play bike on the Sersan Surip highway while the girls just going around the alley and then going back to the starting place"

Children's play area in a densely populated are very limited, the boys can play in the large area while girls can only play in the narrow passage near the house. According to Tyson (2006, p. 85), Swain (2006), and Bartholomaeus (2012), based on traditional gender roles, men are rational and powerful figure. In contrast, women are emotional figure (irrational) and weak, and are known to be nurturing (compassionate) and resigned. 


\subsection{Construction of Gender}

However, in the playground the researchers found a unique behaviour where girls opposed their role in playing areas. Chika is an example for this unique behaviour (pseudonym). Chika is a very brave girl amongst other girls of her age because several times during the research visit, Chika takes part in playing with the boys, such as playing ball, playing bikes, running and other games performed by the boys.

Chika: If you guys are watching me; Chika uses a bicycle with some other boys.

Dadan (the name of the broadcast): hi I want to play

Chika: Dadan you do not tell me I'll fight you when you hit. (Thursday, 3 August 2017).

The position of dominance and subordination in the playground has shown gender inequality, in which the girls can only watch and are prevented from participating in the play area. But there are also girls who showed form of power and dominance. This indicates there is a child who rejects the authority of the male in the play area, making the boys to understand that girls also share the same playground as the boys. One of the most important thing is that in playing activities it let children to build gender roles (Walkerdine, 1981; Davies, 1989, 2003; Thorne, 1993); Blaise, 2014).

\subsection{Mother Perspective Gender}

Boys play with boys and girls plays with girls again. Understanding how mothers practice parenting to children in the playroom still shows that games must be done with the same sex. So it is possible if we still attach an understanding that is rooted in culture and traditional understanding is will still be based on the mother's view. Children who play ball games are deemed inappropriate according to the mother, and research that was done by Mayeza (2016) shows that girls who take part in football is seen as problematic because it blurs the gender binary, under the ways where girls and boys are positioned in opposition to each other.

"When Nana was about to leave wanting to play with some boys who were gathering banging the open car of one of the parked residents, some boys shouted INDONESIA, Nana's mother shouted "Nana here do not go to the boy game "Then the boy returns to his mother and plays the house with the flowers of a 2-year-old child". (Note, Wednesday, July 26, 2017)

Games for boys and girls are different, parents understand that different sexes can define different roles during playing. The results of the observations above suggest that girls like children's play are on the results of observations in this down. Girls like to play cooking cuisine, to play dolls from paper, and to play bicycle in a narrow alley.

The results suggests that girls games were indirectly carried out in the yard close to temporary parents, so it could be stated that women were trained in the domestic space. When girls have a desire to play with the boys, the role of the mother will kick in and the mother will assume that girls play would not play far away from her mother or from their home because it would endanger the child's safety while the boys are left away from the supervision of her parents.

\subsection{Children Perspective Gender}

Children aged six years old can determine which kind of games is suitable for girls and which ones are suitable for the boy. Therefore, children understand that when in the play area girls play with girls, while boys play with boys. Furthermore, children can determine whether a game is suitable for boys or whether it's suitable for girls.

\section{CONCLUSION}

The researcher can conclude that the main criticism of the playroom and gender research is the logic to think biased in the early childhood playroom and the categorization of game choices and playmates. Because girls at the playroom can construct gender by themselves.

The results are consistent with mapping of postdevelopment perspectives that it is a time trend of binary opposition (top-down, east-west, rational-irrational, modern-traditional,) where it has been eliminated in the paradigm of thinking because there has been a bias for adults about the meaning of being single and one-way nature. In the context of male and female relations, there is no discrimination but one must provide equality between men and women.

\section{REFERENCES}

Abdullah, (2007). Pembangunan manusia. Jurnal Populasi, 18(1), ISSN: 0853-0262

Adriany, V. (2013). Hak anak dalam konteks penelitian. In Konferensi Pendidikan Anak Usia Dini dan Pendidikan Dasar SPs UPI "Menyongsong generasi emas 2045” (pp. 579-585). Ed. Hartati, T., Agustin, M., \& Somantri, M. Bandung: Program Studi Pendidikan Dasar

Adriany, V., \& Warin, J. (2014). Preschool teachers' approaches to care and gender differences within a child-centred pedagogy: findings from an Indonesian 
kindergarten. International Journal of Early Years Education, 22(3), 315-328.

AERA Concil. (2011). Code of ethics: American educational research association. Educational Researcher, 40(3), 146-156

Al-Wasilah. (2015) Pokonya study kasus, pendekatan kualitatif. Jakarta: PT Dunia Pustaka Jaya

Bartholomaeus, C. (2016). " I " m not allowed wrestling stuff': Hegemonic masculinity and primary school boys. Journal of Sociology

Bartholomaeus, J. H., Arkenau-Marić, E., \& Galia, E. (2012). Opioid extended-release tablets with improved tamper-resistant properties. Expert Opinion On Drug Delivery, 9(8), 879-891.

Baskara, M. (2011). Prinsip pengendalian perancangan taman bermain anak di ruang publik. Jurnal Lanskap Indonesia, 3(1).

Blaise. (2014). Gender Discourses and Play, London: The Sage Handbook of Play And Learning In Early Childhood

Bodrova, E., \& Leong, D. J. (2013). Play and selfregulation, lessons from pygotsky. American Journal of Play, 6(1), 111-123.

Bowen, Z. (2016). South asian history and culture play on the mother-ground: Children's games in rural Odisha. Journal South Asian History and Culture, 6(3), 330-347.

British Educational Research Association. (2011). Ethical guidelines for educational research.

Chapman, R. (2017). A case study of gendered play in preschools: how early childhood educators' perceptions of gender influence children's play. Journal Early Child Development and Care, 186(8), 1271-1284

Charmaz, K. (1990). “Disscovering”chronic illness: Using grounded theory. Social Science Medicine, 30, 269-288.

Charmaz, K. (2000). Grounded theory: Objectivist and constructivist methods. In N.K. Denzin \& Y.S Lincoln (Eds,). Handbook of qualitative research (Edisi ke2,hlm.509-535). Thousend Oaks, CA:Sage

Charmaz, K. (2006). Constructing grounded theory, London: Sage.
Clark, S., Paechter, C., (2007). dynamics and the playground "Why can " $t$ girls play football ?' Gender dynamics and the playground, Educational Studies, Goldsmiths College, New Cross, London SE14 6NW UK, 37-41.

Cope. (2004). Placing gendered political acts. In: Lynn Staeheli, Eleonore Kofman \& Linda J. Peake (Eds) Mapping women, making politics: Feminist perspectives on political geography, pp. 71-86 (New York, Routledge).

Cresswell, J. W. (2015). 30 essential skills for the qualitative researcher. Sage Publications.

Cresswell, M. J. (2016). Logics and languages. Routledge.

Davies, B. (1989). Education for sexism: A theoretical analysis of the sex/gender bias in education. Educational Philosophy and Theory, 21(1), 1-19.

Davies, B. (2003). Frogs and snails and feminist tales: Preschool children and gender. Hampton Press (NJ).

Dewayani, S. (2011). Stories of the intersection: Indonesian" street children" negotiating narratives at the intersection of society, childhood, and work (Doctoral dissertation, University of Illinois at naChampaign).

Fincher, R. (2013). From dualisms to multiplicities: Gendered political practices. In Mapping Women, Making Politics (pp. 53-73). Routledge.

Gold, S. (1972). Nonuse of neighborhood parks. Journal of the American Institute of Planners, 38(6), 369-378.

Harten, N., Olds, T., \& Dollman, J. (2008). The effects of gender, motor skills and play area on the free play activities of 8-11 year old school children. Health \& Place, 14(3), 386-393.

Hesse-Biber, S. N., \& Leavy, P. (2010). The practice of qualitative research. Sage.

Israel, M., \& Hay, I. (2006). Research ethics for social scientists. Sage.

Jun, J., Chen, L., \& Chen, J. J. (2010). Early child development and care gender differences in externalising problems among preschool children: implications for early childhood educators.

Karniol, R., \& Gal-Disegni, M. (2009). The impact of gender-fair versus gender-stereotyped basal readers on 
1st-grade children's gender stereotypes: A natural experiment. Journal of Research in Childhood Education, 23(4), 411-420.

Knoblauch, H. (2013, September). Qualitative methods at the crossroads: Recent developments in interpretive social research. In Forum Qualitative Sozialforschung/Forum: Qualitative Social Research (Vol. 14, No. 3).

Kosanke, N., \& Warner, N. (1990). Creative play areas. Nashville: School-Age Notes.

Fakih, M. (2008). Analisis gender dan transformasi sosial. Yogyakarta: Insist Press.

Mayeza, E. (2017). 'Girls don't play soccer': Children policing gender on the playground in a township primary school in South Africa. Gender and education, 29(4), 476-494.

Mutiah. 2010. Psikologi bermain anak usia dini. Jakarta: Kencana.

Myck-Wayne, J. (2011). Linking theory and practice in teacher education: An analysis of the reflective-inquiry approach to preparing teachers to teach in urban schools (EdD dissertation). University of Southern California. Retrieved from Dissertations and Theses: The Humanities and Social Sciences Collection. (Publication No. AAT 3278478)

Patilima, H. (2004). Persepsi anak mengenai lingkungan kota (Studi kasus Kelurahan Kwitang Jakarta Pusat). Indonesian Journal of Criminology, 3(3), 4247.

Patton-Imani, S. (2002). Redefining the ethics of adoption, race, gender, and class. Law \& Society Review, 36(4), 813-862

Punch, S. (2016). Cross-world and cross-disciplinary dialogue: A more integrated, global approach to childhood studies. Global Studies of Childhood, 6(3), 352-364.

Rönnlund, M. (2015). Schoolyard stories: Processes of gender identity in a 'children's place'. Childhood, 22(1), 85-100.

Saragih, J. F. G. (2001). Telaah terhadap beberapa penelitian berbasis affordances. Jurnal ComTech, 02(02). ISSN 2087-1244 603-612

Saragih, B. (2003). Pembangunan sistem agribisnis di indonesia dan Peranan public relation. SOCA: Jurnal Sosial Ekonomi Pertanian.
Singer, D., \& Singer, J. (2000). Make-believe: Games and activities for imaginative play. Washington, DC: Magination $\operatorname{Pr}$

Spradley, J. P. (2007). Methods of Ethnography. Tiara Wacana, Yogyakarta [Indonesian].

Staeheli, L. A., \& Kofman, E. (2013). Mapping gender, making politics: Toward feminist political geographies. In Mapping Women, Making Politics (pp. 7-19). Routledge.

Swain, J. (2006). Reflections on patterns of masculinity in school settings. Men and masculinities, 8(3), 331349.

Thorne, B. (1993). Gender play: Girls and boys in school. Rutgers University Press.

Walkerdine, V. (1993). Beyond developmentalism?. Theory \& Psychology, 3(4), 451469.

Wall, S. (2014). Focused ethnography: A methodological adaption for social research in emerging contexts.

Wallerstedt, C., \& Pramling, N. (2012). Learning to play in a goal-directed practice. Early Years, 32(1), 515.

Wohlwend, K. E. (2012). The boys who would be princesses: Playing with gender identity intertexts in disney princess transmedia. Gender and education, 24(6), 593-610. 